\title{
"Horns Up!" The Horned Hand as the Emblematic Gesture of the Metal Subculture
}

\author{
Adam E. Nowakowski \\ Carpathian State College in Krosno, Poland \\ adam.e.nowakowski@gmail.com
}

\begin{abstract}
The horned hand is a gesture completed by extending the forefinger and little finger, while holding the middle two fingers down with the thumb. In years past it has been a subject of many discussions, held by researchers working in various fields of science. However, to the best of my knowledge, the role it plays in nonverbal communication between members of the metal subculture still remains a rather uncharted area. This article is an attempt to shed some light on this topic. It presents a definition of an emblematic gesture, based on the works of David Efron, Paul Ekman, William Friesen and Lluis Payrató. It also gives an account of the semiotic diversity of the horned hand (depending on a culture, the gesture can communicate very different messages, ranging from insults and threats to protection from evil). It was established, based on numerous discussions with the so-called metalheads, that they are able to convey five different meanings using the gesture: 1) indicate affiliation with heavy metal music and/or subculture, 2) display identity and/or community, 3) greet each other, 4) bid each other farewell, 5) display appreciation/respect. Research survey showed that more than $70 \%$ of respondents, who consider themselves knowledgeable about the metal subculture, were able to derive a message matching exactly or almost exactly the message intended by the encoder, which allows to declare the emblematic status of the horned hand. However, subjects not familiar with the subculture were much less successful with this task. This shows that gesture's emblematic status is restricted to members of the metalhead community.
\end{abstract}

Keywords: nonverbal communication, metal subculture, the horned hand, emblematic gestures, Metal Studies

\section{Streszczenie}

”Horns Up!" Dłoń rogata jako gest emblematyczny subkultury metalowej

Charakterystyczny gest dtoni rogatej wykonuje się dtonia prostując palec wskazujacy i mały przy równocześnie zwiniętych palcach środkowym i serdecznym oraz kciuku. Od dluższego czasu budzi on zainteresowanie badaczy reprezentujacych szerokie spektrum dziedzin $i$ dyscyplin nauki. Wielostronna rola, jaką odgrywa w komunikacji niewerbalnej wśród członków subkultury metalowej (uważajacej go za swój symbol), pozostawała jednak do tej pory względnie niezbadana. Niniejszy artykut stanowi próbę wypetnienia tej luki. Przedstawiono w 
nim definicje emblematu, bazują na ustaleniach Davida Efrona, Paula Ekmana, Williama Friesena oraz Lluísa Payrató. Zasygnalizowano także niezwykłe zróżnicowanie semiotyczne danego gestu, który, w zależności od kultury, może oznaczać między innymi obelge, groźbę lub ochrone przed złem. Na podstawie rozmów z licznymi członkami subkultury metalowej określono sensy intencjonalne i kontekst występowania dłoni rogatej wśród nich. Ustalono, że $w$ ich środowisku przy pomocy gestu można: 1) implikować zwiazek z heavy metalem lub subkultura metalowa, 2) wyrażać tożsamość subkulturowa, 3) sygnalizować powitanie, 4) sygnalizować pożegnanie, 5) okazywać szacunek. Przy pomocy ankiety badawczej udało się zdeterminować status emblematyczny dłoni rogatej wśród członków subkultury metalowej (więcej niż 70\% badanych było $w$ stanie zdekodować wszystkie pięć znaczeń). Tymczasem respondenci, którzy nie zadeklarowali przynależności do subkultury, poradzili sobie z postawionym zadaniem znacznie gorzej. Pozwala to skonkludować, że status emblematyczny dtoni rogatej ograniczony jest do subkultury metalowej.

Stowa kluczowe: komunikacja niewerbalna, subkultura metalowa, dtoń rogata, gesty emblematyczne, Metal Studies

\section{Introduction}

The horned hand is distinct gesture known under many names: sign of the horns, the devil horns, or mano cornuta in Italian, to name but a few. It is completed by extending the forefinger and little finger, while holding the middle two fingers down with the thumb. In years past the gesture has been a subject of numerous discussions, some focusing on its unclear etymology and ancient cultural presence (ex. Krüger 2004; Mertzani 2018), others on its supposed occult connotations (ex. Gajewski 2002). Naturally, many studies in the field of nonverbal communication have also featured passages on the horned hand (ex. Morris 1994; Knapp, Hall 2000; Butovskaya 2004; Morris 2009; Ting-Toomey, Chung 2012; McNeill 2014). However, the latter were almost exclusively devoted to the cultural specificity of gestures, since the culturally dependent semiotic diversity of the horned hand is striking. Its meaning can vary from 'cuckold' (in Spain, Portugal, Italy and Malta), or 'symbol of the University of Texas' (in the USA), to 'protection from the evil eye' (in Italy and Malta), or 'threat of removing one's eyes' (in Russia). ${ }^{1}$

That said, the horned hand is also a significant visual attribute of the music genre 'metal' subculture, a key element of its semiotic code and the subculture's "most enduring symbol"

\footnotetext{
${ }^{1}$ Quite interestingly, two major political figures of the turn of the 20th and 21st centuries, President of the United States George W. Bush and Prime Minister of Italy Silvio Berlusconi, were at one point photographed performing the horned hand. However, in the first case, the gesture was used respectfully, as the hand signal of the University of Texas (the so-called Hook 'em Horns), while in the second - as an insult aimed at Josep Piqué, the foreign minister of Spain, implying that his wife is unfaithful to him (later Berlusconi explained that he was "just joking").
} 
(Dunn 2005). Moreover, through the lens of communication studies, the gesture is a potent emblem used among 'metalheads' (i.e. members of metal subculture) to perform a variety of illocutionary acts in various communication contexts. However, to the best of my knowledge, this function has been largely omitted in previous studies. ${ }^{2}$

The aim of this paper is to analyze the horned hand as an emblematic gesture of, specifically, the metal subculture (i.e. used by metalheads differently than by non-metalheads), describe its contexts of occurrence among metalheads and intentional senses that can be conveyed by its symbolism.

\section{Emblematic gestures}

Scientific studies of 'emblems' or 'emblematic gestures' were established with David Efron's (1941) pioneering comparative work on gestural behavior of Southern Italian and East European Jewish immigrants living in Manhattan. Efron's study became a foundation for Paul Ekman's and Wallace Friesen's ([1969] 1981) highly influential classification of gestures. In order to avoid terminological chaos, they took some of Efron's terms, even though often they defined them differently. They named one particular category of nonverbal behavior 'emblems', whereas Efron talked about 'emblematic gestures'.

Ekman's and Friesen's ([1969] 1981) classification included a number of necessary conditions for gestures that need to be met in order to achieve emblematic status. Firstly, they defined emblems as nonverbal acts, autonomous from verbal behavior, that have a direct verbal equivalent, usually in a form of a word, or a phrase. Secondly, emblems are used intentionally and consciously, often depending on a communication context, similarly to verbal behavior, but unlike some other categories of gestures. Finally, they are highly conventionalized, they can be coded arbitrarily or iconically and their decoded meaning must be shared across a group of individuals, ranging from small conspiratorial organizations to whole cultures. Naturally, their meaning is culturally determined and might vary.

\footnotetext{
${ }^{2}$ Despite the emergence of so-called Metal Studies in the late 2000s, the metal subculture remains a rather uncharted territory for academic studies. The situation is changing though, with the steadily rising number of papers, books and even dissertations in this interdisciplinary field, and thanks to the existence of The International Society for Metal Music Studies. In the words of Albert Bell (personal communication, June 24, 2016), a fellow academic and a musician whom I had a privilege to interview for Heavy Metal Pages magazine, Metal Studies is "a field that invites researchers with a common interest in metal music to come together and look at heavy metal from an academic perspective, not simply from a fan perspective. (...) They possess deeprooted experience in the music scene (as musicians, producers, or consumers), as well as research expertise." This approach allows them to achieve a unique perspective on issues regarding heavy metal. For a broader overview, see: Baka 2018.
} 
Subsequent scholars often set aside the original terminology in favor of such terms, among others, as 'semiotic gestures' (Barakat 1973), 'symbolic gestures' (Dul 1993), 'conventionalized gestures' (Jarząbek 1994), and, most famously, 'autonomous gestures' or 'quotable gestures' (Kendon 1981). The introduction of new terms reflects differences, often minor, in how various scholars define this particular class of gestures. This is evocative of a broader issue, which is that providing a firm and universally recognized Aristotelian-type definition of an emblem has proven to be very difficult, if not impossible. The reason for that is that emblems, their properties and even forms, cannot be described using absolutes, but rather a scale. This is why Lluís Payrató has taken a cognitive approach in order to define emblems.

Drawing on the theory of prototypes, Payrató (Payrató, Clemente 2020) synthetized recurring features of prior definitions of emblems and redefined the category with the following list of five attributes:

1) Autonomy of speech,

2) Communicative goal (intentional and deliberate),

3) Illocutionary force,

4) Social nature,

5) Semantic core.

\section{The horned hand}

The semiotic journey, so to speak, of the horned hand is a rather intriguing one. The gesture originated in the ancient times. One of its earliest depictions known is over 4000 years old and can be seen in the Qar tomb, which dates back to the sixth Egyptian Dynasty. It was both a solar and a lunar gesture. It represented the day and the night, the beginning and the end, which explains its presence in burial chambers.

As a solar gesture, the horned hand was linked to the cow and the bull, which symbolized the sun in Egyptian, Minoan and Mycenaean civilizations. As a lunar gesture, in the Mediterranean Region it was connected to the cult of fertility (Mertzani 2018). Even in present times it is used as a protective gesture in most parts of Italy and on Malta (Morris 1994). When performed (horizontally, not vertically), or worn as an amulet, the horned hand is believed to provide protection from the evil eye, which can cause infertility, among other harms. ${ }^{3}$ Quite

\footnotetext{
${ }^{3}$ The horned had is used as a protective symbol also in Buddhism and Hinduism (Robrue, Poungplub 2014). However, given Western provenance of metal subculture, in this section I am focusing on its meaning primarily in the Western civilization.
} 
notably the gesture appears in Bram Stoker's Dracula, when Jonathan Harker is about to leave for the Count's castle:

When we started, the crowd round the inn door, which had by this time swelled to a considerable size, all made the sign of the cross and pointed two fingers towards me. With some difficulty I got a fellow-passenger to tell me what they meant; he would not answer at first, but on learning that I was English, he explained that it was a charm or guard against the evil eye.

(Stoker [1897] 1983 6-7)

Consecutively, in Ancient Greece and Ancient Rome the horned hand was one of several gestures used by professional orators in their delivery of speeches. Quintilian (1920: 295) described it as "producing a still more forcible effect" than simply placing the middle finger against the thumb and extending the remaining three, which was "one of the commonest of all the gestures." The oratory usage of the horned hand later re-emerged in the Byzantine Empire, and was depicted on Eastern Orthodox Christian icons. In this context the gesture could be verbally paraphrased as "Wise we shall listen!" (Renev 2016). In the same meaning the gesture was later used on Russian icons as well. Surprisingly, in modern Russia, when presented vertically, the horned hand was also used by criminals as a nonverbal threat. It was later adopted by the so-called New Russians ${ }^{4}$, and used as a means of expressing one's superiority (Navasartova 2017).

Finally, by the early 1980s the horned hand was adopted and is still used across cultures and borders as a symbol of the metal subculture. The gesture was introduced by Ronnie James Dio, a famed American vocalist of Italian descent, who had learnt it from his grandmother. ${ }^{5} \mathrm{He}$ would frequently see her use it as protection from the evil eye, as she was quite superstitious (Dunn 2005). Dio was known for his powerful voice, fantasy-driven lyrics, and theatrical stage presence. The horned hand became an intricate part of his stage repertoire and his trademark. During a concert on Long Island in 1980 he explained it as a sign of unity and shared support of rock music:

${ }^{4}$ New Russians were a newly rich business class, often with ties to mafia, who made their fortune in the 1990s. They became a staple of Russian popular culture, being a popular topic of anecdotes, cabaret sketches, stand-up routines and comedies (Sergeeva 2006).

${ }^{5}$ Even though it is Dio who is most commonly regarded as the popularizer of the horned hand, Gene Simmons (2001) of the group KISS claims that it was actually him who accidentally invented this gesture, as exhibited on the cover of the 1977 album Love Gun. In 2017 Simmons even undertook a failed attempted to trademark it. The gesture's presence in rock music can actually be traced back even further, to American group Coven and their 1969 debut album Witchcraft Destroys Minds \& Reaps Souls, where it is prominently featured on the back cover. 
You've obviously come to this place because you like rock music, is that right? [audience screams 'yeah' in agreement] And you will come back here to see whoever is a good rock and roll organization, right? [audience once again agrees] Just so you remember, people think this [Dio presents the horned hand] means something other than it really is. If you'll all join us, I will tell you what it really means. It means: long live rock and roll! Put them up! [Dio and audience members present the horned hand].

(A Metalhead's Journey 2019)

Dio would in fact often use the gesture during live performances, especially during his time as the vocalist of Black Sabbath (i.e. 1979-1982, 1991-1992) ${ }^{6}$ - a group commonly regarded as originators of heavy metal music genre. With time, other musicians and members of the metal subculture adopted the horned hand, up to a point when it developed a new meaning - it became the symbol of the community. ${ }^{7}$ Meanwhile gradually the gesture also penetrated the mainstream culture where it became associated with the meaning "to enjoy oneself".

\section{Symbol of the metal subculture}

Despite various accusations against the metal subculture made in the past decades mostly by people associated with conservative circles, the metal community as a whole was never bounded by any ideology, or radical beliefs. It was and it still remains a music-based subculture. To quote Albert Bell (personal communication, June 24, 2016) once again:

I don't think we're that different [from non-metalheads]. We might look different, we might act differently, and we might enjoy different things - that's what sets us apart from other people. However, on most levels we're just the same: we love, we hate, we get angry, we have children, we get separated, we get divorced. We face the same life issues. The binding element of the metalhead community is our passion for heavy metal - that's what brings us together. Other than that we are very different individuals, with different ideologies, different life experiences. Our unity comes exclusively from music.

${ }^{6}$ Dio later re-joined Black Sabbath for a short period in 1991-1992, and then formed Heaven \& Hell (20062010) with his fellow Black Sabbath musicians.

${ }^{7}$ I strongly believe claims of metalheads misusing the horned hand as a result of being "unaware of its real meaning" (Robrue, Poungplub 2016: 291) to be false. Their usage is generally intentional, but the gesture's well established status within metal circles does not seem to be widely recognized outside of the subculture. Therefore their illocutionary acts might be misunderstood by outsiders, or invite claims of ignorance and/or misusage. 
Attending metal concerts is generally seen as an activity central to the subculture. That is where it thrives and metalheads forge and affirm their identity, values and norms. Unsurprisingly, the horned hand as a symbol of the metal subculture originated namely in such circumstances. Deena Weinstein (1991: 218) calls metal concerts a "semiotic thicket" that in order to be read, requires "decoding a complex array of communicative acts by using the heavy metal codebook." One of these acts involves presenting the horned hand ("throwing up the horns") upon a request by musicians performing on stage. As Weinstein (1991: 224) notices, "getting the audience to behave in harmony with one another is the basic way of forming the concert community." Indeed, as shown by Jolanta Antas and Izabela Kraśnicka-Wilk (2003), synchronic repetition of emblematic gestures brings interlocutors mentally closer together. Such an act of unity refers them to shared cultural scripts, which helps to establish understanding between them. In the case of metalheads, the knowledge of how to use the gesture properly indicates the degree of one's involvement in the subculture.

Metal concerts seem to create the most natural environment for usage of the horned hand, however, the gesture is not restricted only to such events. It is commonly featured in promotional materials (photos, posters etc.), on album covers, in music journals and on merchandise. What began as a secret symbol known only to members of the subculture, with time was introduced to mainstream culture, to metal community's deepest dissatisfaction.

However, while outside the metal community the horned hand serves simply as a symbol of the metal subculture, among metalheads its role is significantly more diverse and subtle. Even though emblematic gestures are said to have a stable semantic core, its meaning is still liable to changes. Such can be caused by communication context, addition of an accompanying verbal message or other nonverbal cues (Knapp, Hall 2000). For example, depending on aforementioned factors, hand-waving can be decoded as 'greeting', 'drawing attention' or 'farewell'.

\section{Research methodology}

In order to characterize extensively the use of the horned hand among metalheads, I implemented a method inspired by Harold G. Johnson, Paul Ekman and Wallace V. Friesen (1975). My research was divided into three phases and conducted via Internet (partly because this paper was written during the COVID-19 pandemic).

The goal of phase one was to identify the largest number of potential communication contexts and intentional senses. This was possible thanks to discussions with participants $(N=$ 
35), who consider themselves involved members of the metalhead community; conducted using social media (Facebook, Discord), as well as my personal experience as a life-long member of the metal subculture. At this point I did not differentiate between metalheads of different nationalities, as I was focused on achieving the quantitative result. That being said, I was able to gather data from, among others, Americans, Poles, Russians, and Swedes. They were asked in their native languages to describe situations in which they perform the horned hand and what kind of messages they mean to convey with it. As a result, I was able to identify a variety of five different communication contexts and intentional senses possibly exclusive to metalheads:

a) Indication of affiliation with heavy metal music and/or subculture

b) Display of identity and/or community

c) Sign of greeting

d) Sign of farewell

e) Display of appreciation/respect

With gathered data, I was able to move to phase two and create an Internet survey. It consisted of pictures and short video clips (no longer than 10 seconds) arranged in random order, depicting communication contexts suggested by my interlocutors, augmented by short descriptions of presented situations. Then the survey was sent to a group of random Polish participants $(N=50)$, highly devoted to the metal subculture. ${ }^{8}$ This group will be later referred to as $\mathrm{M}$. Their task was to determine the meaning behind every presented usage of the horned hand in a written form (in no more than two sentences). Finally, in order to determine whether given examples of the gesture's usage are indeed restricted to metalheads, in phase three I asked a different group of random Polish participants $(N=50)$, who had previously declared no affiliation with the metal subculture, to take the survey conducted in phase two of my research. This group will be later referred to as NM. All answers given by participants in phase two and three were thematically grouped and will be presented in forthcoming tables 1-5.

Measurements used by Johnson, Ekman and Friesen (1975) show that in order to verify an emblematic status of an action pattern, a message derived by at least $70 \%$ of the decoders needs to match exactly or almost exactly the message given by the encoder. In my research I applied the same percentage threshold.

\footnotetext{
8 I believe, that since the metal subculture is a global phenomenon, the results would not have been affected by including members of different nationalities in the research group. However, not being absolutely certain, I decided to focus on a homogeneous group nevertheless.
} 


\section{Results and discussion}

In the result of an extensive analysis of fundamental themes of relational communication, Judee K. Burgoon and Jerold L. Hale (1984) concluded that interactants exchange messages along twelve nonorthogonal communication dimensions. Subsequent research indicated that these dimensions could be combined into fewer, interrelated message clusters: 1) intimacy, 2) emotional arousal/activation, 3) composure, 4) dominance, 5) similarity, 6) formality, 7) task or social orientation (Burgoon, Guerrero, Manusov 2011). Of these, the analyzed messages conveyed using the horned hand should be referred to the first and fifth group.

The intimacy dimension (which encompasses several subthemes related to affection, involvement, inclusion, trust, and depth) concerns expression of affection, as well as efforts to initiate close personal relations with others and to be included in social groups. Nonverbal cues that communicate intimacy include, among others, affectionate touch, soft voices, postural openness, moto mimicry and mirroring. Members of the metal subculture signal a relationship between each other using a variety of nonverbal cues, including mirroring of the horned hand.

Signaling similarity is an essential relational message theme. This dimension (also labeled as identification, or interpersonal solidarity) concerns the degree to which people share similar values, norms, personal characteristics, experiences, as well as specific displays that are unique to a given class of communicators and that help to set that class apart from others. In the case of metalheads, nonverbal cues that communicate similarity often include physical appearance (ex. growing hair long, wearing T-shirts with the emblem of musical groups), and specific communication practices during dyadic and group interactions, some of which involve the horned hand.

\subsection{Indication of affiliation with heavy metal music and/or subculture}

In its most basic sense, the horned hand is a symbol which simply refers to heavy metal music and/or subculture. This meaning transcends the metal subculture, since the gesture is now an integral part of global culture, sometimes used with meaning of "to enjoy oneself enthusiastically." It can be seen in a variety of visual media, often not affiliated with heavy metal. The overexposure of the horned hand in mass media, and especially its embracement by 
pop singers (ex. Britney Spears, Avril Lavigne, Miley Cyrus) has led to some members of the community refraining themselves from using the gesture entirely or using it in an ironic way. ${ }^{9}$

The research survey included the following album cover. It prominently features the horned hand as an indicator of affiliation with heavy metal. Participants were asked to speculate on the genre of music on the album, judging exclusively by the image.

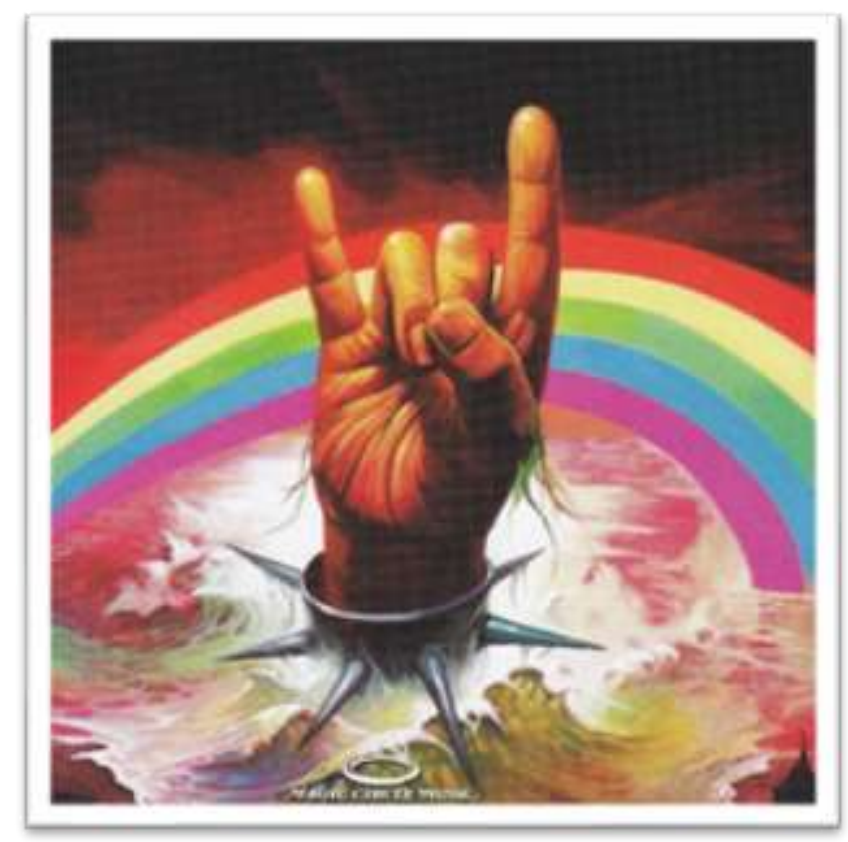

Figure 1. Magic: A Tribute to Ronnie James Dio. Source: Kelly 2010.

The presented artwork by Ken Kelly was used on the inside cover of Magic: A Tribute to Ronnie James Dio, which is a compilation album commemorating Dio's music. It features interpretations of several songs originally sung by him. The image is a play on the cover artwork used on Rising by Rainbow, but it shows a horned hand, whereas the original version (also painted by Kelly) featured a clenched fist. The artwork is rather unusual for hard rock or heavy metal conventions, thus guaranteeing that the featured gesture was the only clue for participants, something that they all focused on.

The conducted survey seems to confirm the universal recognition of the horned hand as the symbol of heavy metal. Not only $100 \%$ of participants of Group M were able to decipher

\footnotetext{
${ }^{9}$ There are also initiatives among the metalhead community (rather destined to fail) aimed at "taking the horned hand back." As one group on Facebook, which has almost 9000 likes, states: "If you don't know why you're using Devil Horns, STOP using them. If you're a fan of Nickleback, Blink 182, Linkin Park or Hannah Montana - STOP using Devil Horns. If you've never heard of Ronnie James Dio - STOP using Devil Horns."
} 
the meaning, but so did 74\% of participants of Group NM. They agreed that the gesture on the cover art indicates that the album probably contains heavy metal music.

Table 1. Judging by the cover, what genre of music does this album fall under? Source: author.

\begin{tabular}{|l|c|}
\cline { 2 - 2 } \multicolumn{1}{c|}{} & Group $\mathbf{M}$ \\
\hline $100 \%$ & metal / heavy metal \\
\hline
\end{tabular}

\begin{tabular}{|c|c|}
\cline { 2 - 2 } \multicolumn{1}{c|}{} & Group NM \\
\hline $74 \%$ & metal / heavy metal \\
\hline $20 \%$ & Rock \\
\hline $6 \%$ & I don't know \\
\hline
\end{tabular}

\subsection{Display of identity and/or community}

Being a prevalent symbol of the metal subculture, the horned hand is often used as a means of displaying group identity and/or community. The verbal equivalent of this act could be summarized in a simple but powerful assertion: "This is/I am/We are metal!" It seems that the most common context, in which such a declaration is made, is either during a live event (such as festival or concert), or when posing for photograph. ${ }^{10}$ In fact, these circumstances naturally coincide quite often. Large gatherings are a perfect occasion to celebrate and demonstrate group identity as metalheads. Musicians play an integral part in this, using the horned hand to express solidarity with audience members, by performing the gesture on stage. Audience members then mirror it as a sign of confirmation: "Yes, all of us here are metal."

When the horned hand is used for display of identity, some variety in the way how the gesture is performed is allowed. Consequently, horns can be aimed horizontally or vertically. If vertically, the palm might be facing either the sender or the receiver. The gesture is also able to convey different levels of intensity. Accompanying facial expressions play an integral part in this act, as spectrum of emotions displayed through this channel of nonverbal communication ranges from anger to euphoria. The gesture can be reinforced when performed using both hands and/or when accompanied by a paraverbal or verbal cue, such as shouting. Is can also be performed while flexing biceps, which seems to result in higher intensity of the delivered statement.

\footnotetext{
${ }^{10}$ One of my interlocutors, Didier Goossens, mentioned to me in conversation that in the past he would often perform the horned hand in family or high school photographs in order to "delineate his own identity in relation to his family and members of high school communities." (personal communication, June 29, 2020)
} 


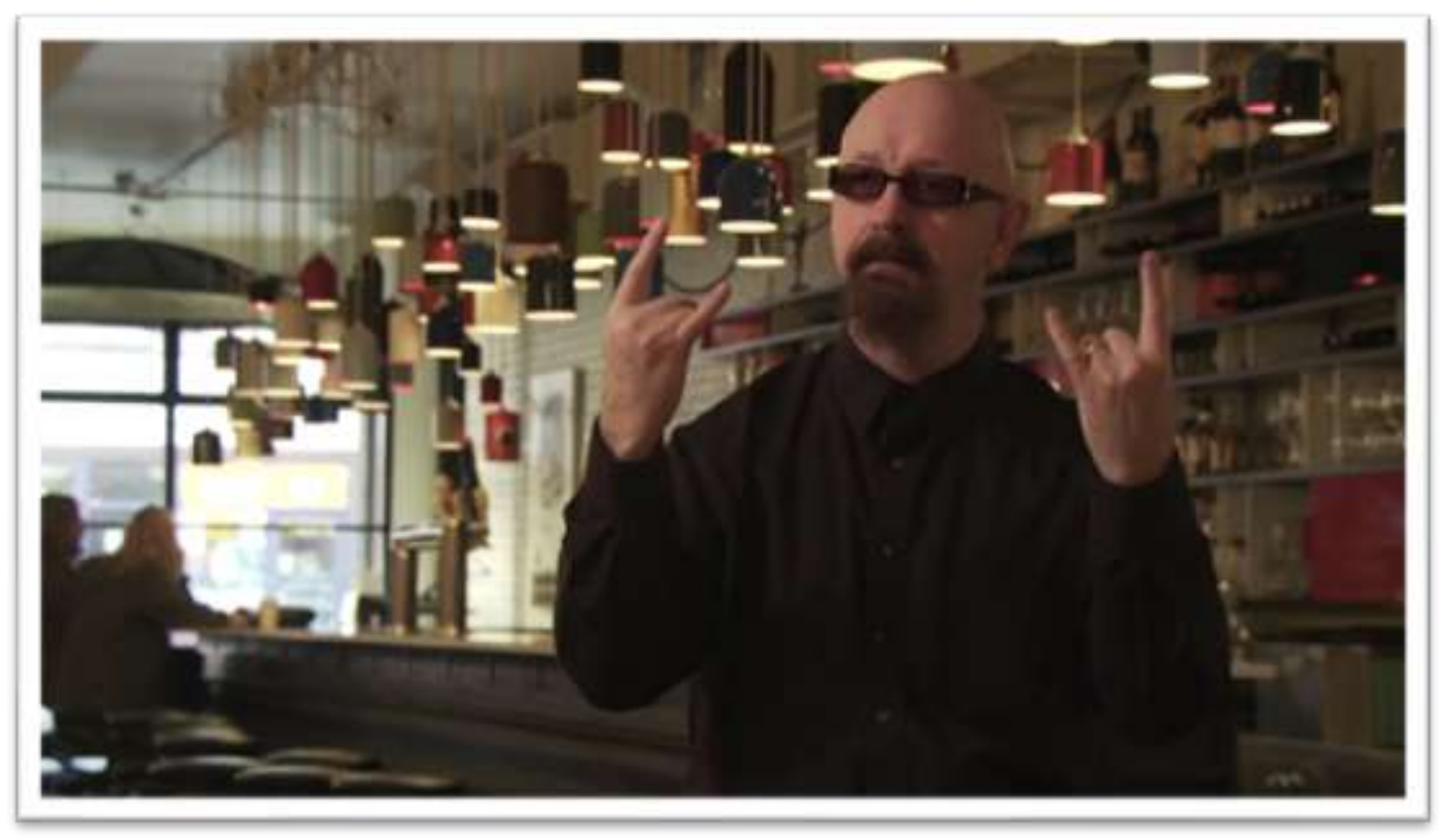

Figure 2. "We're heavy metal." Source: Dunn and McFadyen 2011.

The survey included a short video clip catching a metalhead using the horned hand to display his identity. It features singer Rob Halford elaborating on how Judas Priest was the first group to establish the distinctive look of heavy metal culture, and why simply playing the music is one issue, while having a look that represents the sound is a separate one. For them it was a manifest: "We are what we are, we believe in what we do." Then Halford adds: "We're Judas Priest. We're heavy metal" and follows his statement with a dual horned hand.

My discussions with metalheads revealed that they consciously diversify usage of the horned hand depending on whether they interact with other members of the community, or with outsiders. In the former case, the gesture is more meaningful and is able to convey more types of messages, which otherwise remain hidden to non-metalheads. The results of the survey reflect this quite well, because $82 \%$ of participants of Group M interpreted the presented video as display of metal identity/community/solidarity, while only $34 \%$ of participants of Group $\mathrm{NM}$ came to the same conclusion. It is also rather telling that many answers given by the former included rather emotional vocabulary: "He's one of us", "He's a member of the metal family", "Metal runs through his blood" etc. 
Table 2. What is Rob Halford communicating with this gesture? Source: author.

\begin{tabular}{|c|c|}
\cline { 2 - 2 } \multicolumn{1}{c|}{} & Group M \\
\hline $82 \%$ & He identifies as a metalhead \\
\hline $16 \%$ & He plays metal \\
\hline $2 \%$ & I don't know \\
\hline
\end{tabular}

\begin{tabular}{|c|c|}
\cline { 2 - 2 } \multicolumn{1}{c|}{} & Group NM \\
\hline $44 \%$ & I don't know \\
\hline $34 \%$ & He identifies as a metalhead \\
\hline $14 \%$ & He plays rock \\
\hline $8 \%$ & He worships Satan \\
\hline
\end{tabular}

\subsection{Sign of greeting}

Among metalheads, the horned hand is also used in accordance with their informal code of politeness as a sign of welcome or recognition, prior to an interaction, or to greet in passing. Since this usage is limited to members of the metal community, it automatically indicates the membership as well. Similarly, as with other gestures of greeting, the sender directs the horned hand at the receiver as a means to make his or her presence known, and to suggest a cordial relationship. The gesture is then reciprocated by the receiver for the sake of symmetrical interaction. This act of greeting is fully sufficient and does not need to be accompanied by any further nonverbal behavior, or a verbal message.

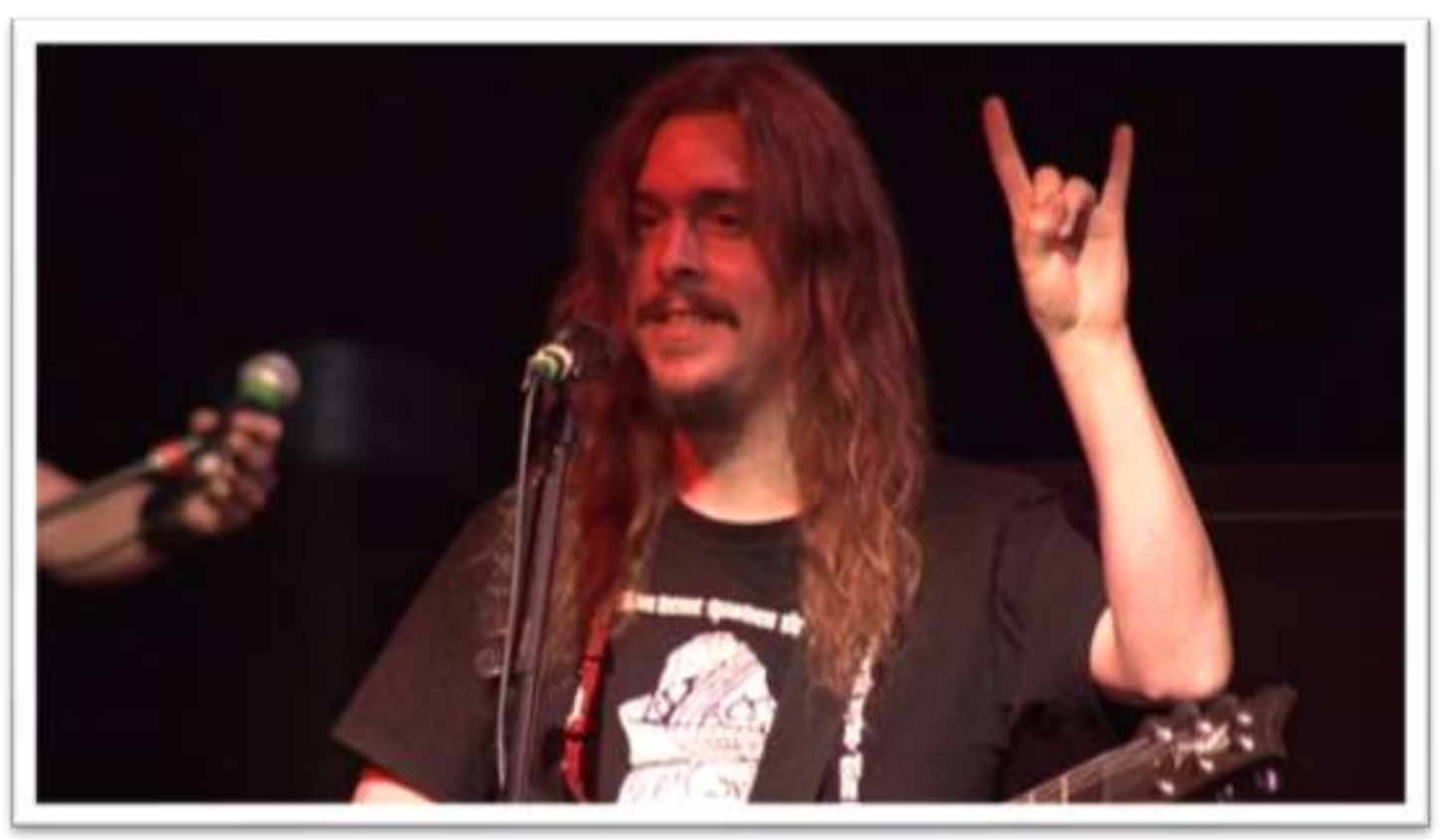

Figure 3. The concert is about to begin. Source: Opeth 2007. 
The research survey included a short video footage presenting Mikael Åkerfeldt of the Swedish group Opeth using the horned hand (without any accompanying verbal messages) to welcome audience members to the concert, as the group prepares on the stage to start their performance.

As with most gestures of greeting, the context of usage of the horned hand with a given intention is rather telling. Thus, a perceptive individual should be able to construe this meaning even without prior knowledge of how metalheads may greet each other. Especially since survey participants were informed that the presented scene is happening prior to concert beginning. According to the survey, $86 \%$ of participants of Group M and 44\% participants of Group NM interpreted the presented material as depiction of greeting.

Table 3. What is Mikael Åkerfeldt communicating with this gesture? Source: author.

\begin{tabular}{|c|c|}
\cline { 2 - 2 } \multicolumn{1}{c|}{} & Group $\mathbf{M}$ \\
\hline $86 \%$ & Welcome to the concert \\
\hline $14 \%$ & Let's enjoy ourselves \\
\hline
\end{tabular}

\begin{tabular}{|c|c|}
\cline { 2 - 2 } \multicolumn{1}{c|}{} & Group NM \\
\hline $44 \%$ & Welcome to the concert \\
\hline $26 \%$ & Let's enjoy ourselves \\
\hline $20 \%$ & He identifies as a metalhead \\
\hline $6 \%$ & Hail Satan \\
\hline $4 \%$ & I don't know \\
\hline
\end{tabular}

\subsection{Sign of farewell}

Just like numerous greeting gestures (e.g. hand wave, or hand shake), the horned hand serves a double function and can also be used to mark one's departure and thus end an interaction. In this case the rules of usage are the same as the ones stated above, however the communication context obviously differs. The survey included a short video showing members of German thrash metal group Kreator leaving the stage after the concert has concluded, and signifying their departure by performing the horned hand, instead of such universally understood nonverbal cues as a raised hand or a hand wave. 


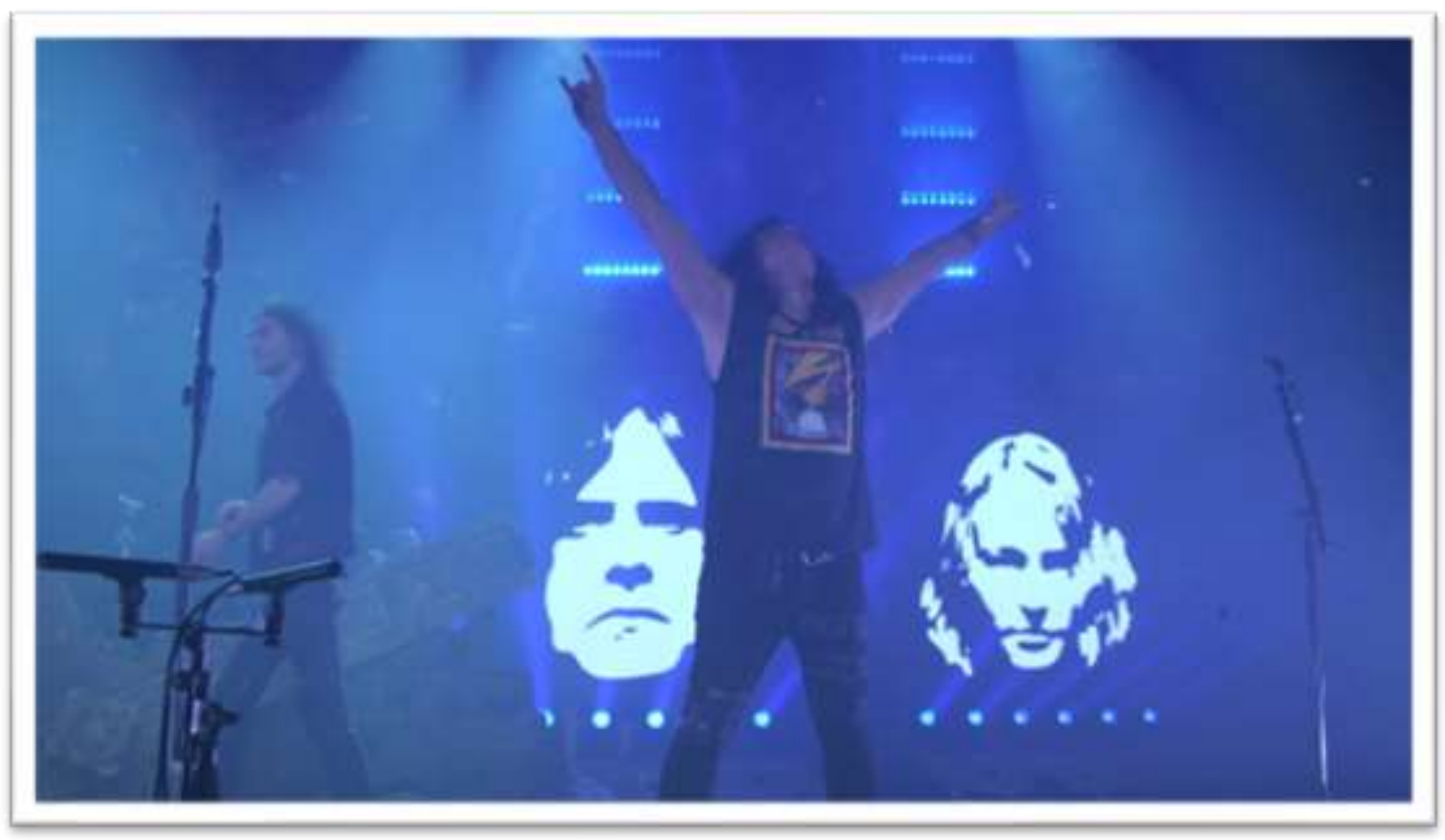

Figure 4. The group is leaving the stage. Source: Kreator 2020.

According to the survey, message of farewell conveyed with the horned hand was clear to $80 \%$ of participants of Group M and 30\% participants of Group NM. As with previous example, also here the communication context is quite revealing, so the task of deciphering the intended message was rather easy even to participants unaccustomed to the metal subculture.

Table 4. What is Mille Petrozza communicating with this gesture? Source: author.

\begin{tabular}{|c|c|}
\cline { 2 - 2 } \multicolumn{1}{c|}{} & Group $\mathbf{M}$ \\
\hline $80 \%$ & Goodbye \\
\hline $16 \%$ & That was great \\
\hline $4 \%$ & He identifies as a metalhead \\
\hline
\end{tabular}

\begin{tabular}{|c|c|}
\cline { 2 - 2 } \multicolumn{1}{c|}{} & Group NM \\
\hline $38 \%$ & He identifies as a metalhead \\
\hline $30 \%$ & Goodbye \\
\hline $24 \%$ & I don't know \\
\hline $8 \%$ & Hail Satan \\
\hline
\end{tabular}

\subsection{Display of appreciation/respect}

Finally, the horned hand can also be used to express positive evaluation, particularly towards a musical group performing on stage. In this context the gesture is a nonverbal communication act of politeness equivalent to applauding. 
The heavy metal concert milieu equips audience members with a particular repertoire of actions which allow them to express their satisfaction with performance. That is slightly different than the one available, for instance, to spectators of an opera. Possibly the one most commonly used is raising a hand high in the air (vertically, or in a circa forty degree angle), and showing the horned hand towards musicians ("throwing up the horns"). This act can be additionally reinforced, if necessary, by performing the gesture with both hands, and/or cheering loudly.

This usage is, however, not restricted exclusively to concerts. The horned hand can also be used to express respect towards another member of community, although in such cases a complementary verbal message is often required for clear and precise communication. An anonymous Discord user shared this example with me: "I'm a young metalhead who wears metal gear. Sometimes older people walk by me and go: 'Nice vest dude', or 'I saw them back in ' 87 ', or 'Fun to see younger metal folks'. And show the devil horns as a proper sign of respect." (personal communication, May 20, 2020)

The research survey included a short video showing concert audience members praising a musical group between songs. The frame presented below was taken from a tracking shot on metalheads reacting to a performance by the American death metal group Obituary. Most of them are presenting the horned hand while others are applauding.

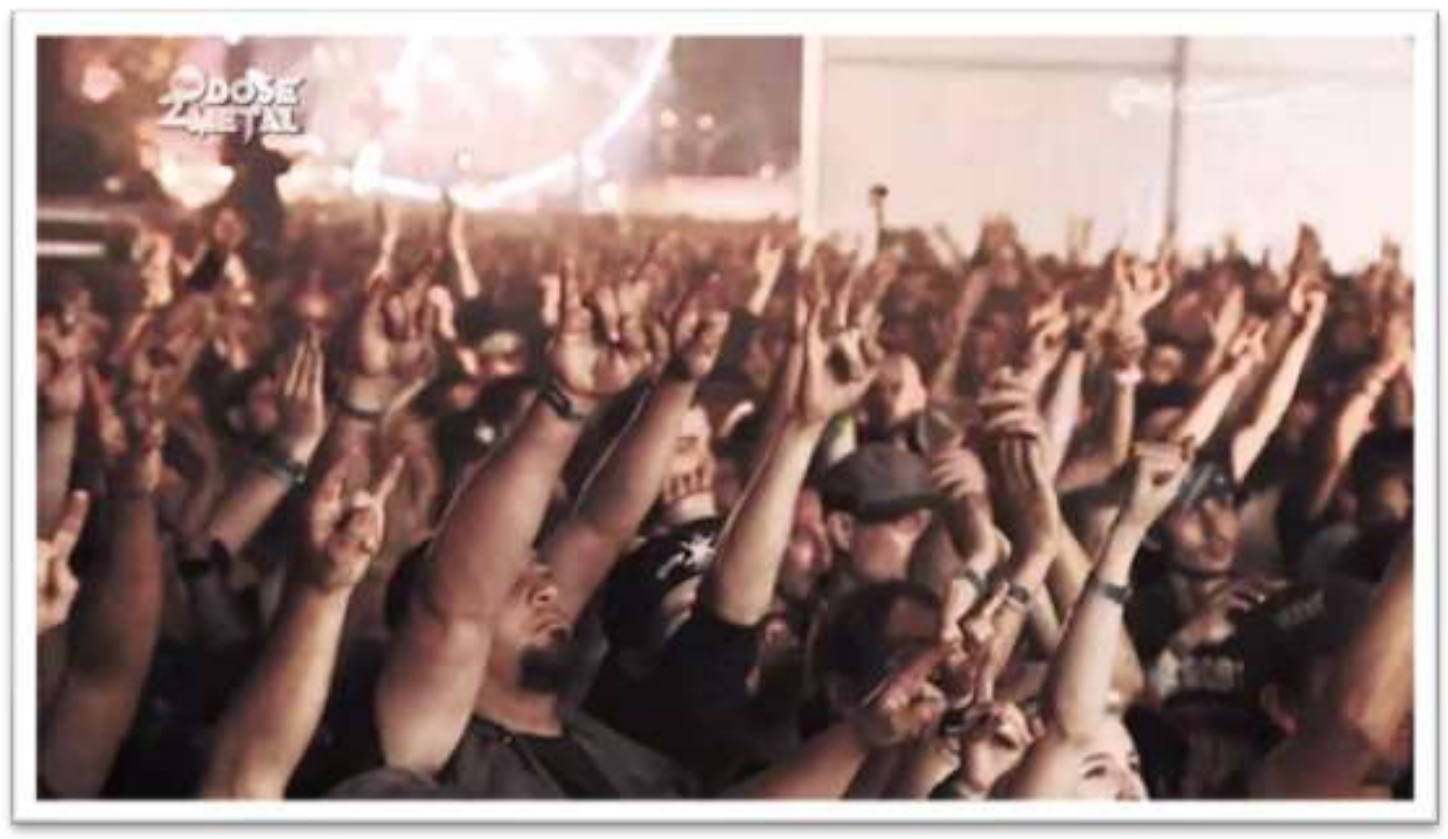

Figure 5. The concert is going well. Source: Obituary 2015. 
The survey conducted shows that $92 \%$ of participants of Group M were able to match the intended message exactly, which is understandable, since this particular usage of the horned hand is very common, and attending even one heavy metal concert allows an individual to introduce this behavior to their repertoire. Meanwhile only $18 \%$ of participants of Group MN succeeded in deciphering the message. This small percentage of correct answers could probably be explained by the fact that metal concerts rarely gather audience that is not already affiliated with the metal subculture. Because of this, non-metalheads are not often exposed to such acts of internal community communication.

Table 5. What is the audience communicating with this gesture? Source: author.

\begin{tabular}{|c|c|}
\cline { 2 - 2 } \multicolumn{1}{c|}{} & Group $\mathbf{M}$ \\
\hline $92 \%$ & Well done / You're great \\
\hline $8 \%$ & We're all metalheads \\
\hline
\end{tabular}

\begin{tabular}{|c|c|}
\cline { 2 - 2 } \multicolumn{1}{c|}{} & Group NM \\
\hline $34 \%$ & I don't know / Nothing \\
\hline $32 \%$ & We're all metalheads \\
\hline $18 \%$ & Well done / You're great \\
\hline $16 \%$ & Hail Satan \\
\hline
\end{tabular}

\section{Conclusions and further research}

As established, the horned hand is a symbol of the metal subculture. It is widely recognized as such not only among its members, but also individuals not highly familiar with customs of metalheads. However, while the latter see it simply as a reference to heavy metal music and the community developed around it, in certain communication contexts metalheads are able to use the gesture to convey more meaningful and detailed information, i.e. to display their identity and/or community, greet and bid each other farewell, show appreciation and/or respect.

Research shows that more than $70 \%$ of respondents who consider themselves knowledgeable about the subculture, were able to derive a message matching exactly or almost exactly the message intended by the encoder, which allows to declare the emblematic status of the horned hand. Consecutively, subjects who do not believe themselves to be familiar with the subculture were much less successful with this task. This shows that gesture's emblematic status is restricted to members of the metalhead community.

It should be addressed that while not a single participant of Group M claimed the horned hand to be a sign of allegiance to the devil, such answer did occur among participants of Group 
NM. This issue is well deserving of a separate study - one of auto- and hetero-images of metalheads. The brief explanation is that there is a striking discrepancy between how members of the subculture perceive themselves and how they are perceived by outsiders. Only a fraction of metalheads treat satanic elements, present in lyrics and the image of selected musical groups, as more than an act, a purely stylistic choice, or an element of the metal aesthetics. However, outsiders lack this understanding and therefore might believe them to be actual Satanists. Although unintended, the survey does show this perceptional divide.

Finally, the process of developing this paper has revealed several additional topics related to communication in the metal subculture. I would like to propose them for future research and discussion. These are as follows:

- What other nonverbal behaviors establish the repertoire of ritualistic actions that take place during a heavy metal concert? ${ }^{11}$

- What acts of verbal communication partake in forming the concert community? ${ }^{12}$

- To what degree is concert behavior of metalheads culturally determined ${ }^{13}$

- How much can the horned hand differ in performance until it is no longer recognizable ${ }^{14}$

- Lastly, written communication is not usually considered a domain of nonverbal communication, therefore I did not study the usage of the horned hand emoticon. It is, however, a goal worth pursuing. ${ }^{15}$

\footnotetext{
${ }^{11}$ There are many rituals particular to heavy metal concerts in general, as well as to live performances of specific musical groups. A rather unique concert practice, which can be observed among devoted supporters of German power metal group Blind Guardian, is sitting down cross-legged when the iconic The Bard's Song is played. Interestingly, audience members are not verbally invited to do so. To them this behavior is a common knowledge.

12 One of better known examples, that has been repeated at numerous concerts, is Bruce Dickinson's catchphrase "scream for me" followed by the name of a city or country.

${ }^{13}$ To give an example of a behavior deeply rooted in local culture, Kobi Farhi of Israeli progressive metal group Orphaned Land mentions that during their concerts in Turkey audience members often sing along with them, with hands placed slightly in front and to the sides of the head, which is a gesture that Muslims perform during a prayer (Dunn, McFadyen 2007).

${ }^{14}$ As mentioned earlier, the horned hand can be performed vertically or horizontally, the palm may be facing the sender or the receiver, the handshape may resemble letter $\mathrm{H}$ or Y. However, it is unclear when it becomes an entirely different gesture.

${ }^{15}$ There even seems to be a difference in perlocutionary effect between written and graphic form, i.e. typing $1 \mathrm{~m} /$ and using a pre-formatted emoticon. The former is considered to be more authentic, more in agreement with the subculture's ethos.
} 


\section{Acknowledgements}

I wish to express my deepest gratitude to:

JOLANTA ANTAS (Jagiellonian University, Poland) for leading me on a journey to write this paper.

GERARD MCCANN (St Mary's University College Belfast, Northern Ireland) for insightful comments on the first version of this paper.

Participants of my research survey and discussions on issues concerning the metal subculture. Especially JÁNOS FEJES (Pázmány Péter Catholic University, Hungary) and DIDIER GoOSSENS (Erasmus University Rotterdam, Netherlands).

Tertium Linguistic Journal reviewers for a close reading of my paper and their inspirational comments and invaluable suggestions.

\section{References}

A Metalhead's Journey. Ronnie James DIO Introduces the Devil Horns - Long Island, 1980.

[Retrieved from: https://youtu.be/51GAikH6oHQ. Date: 12-05-2019].

Antas, Jolanta, Izabela Kraśnicka-Wilk (2013) "Funkcje emblematów w strukturze dialogu."

LingVaria 8 (16); 15-42. http://dx.doi.org10.12797/LV.08.2013.16.02.

Baka, Anna (2018) “Metal Studies - historia powstania i przegląd badań.” Annales Universitatis

Paedagogicae Cracoviensis. Studia de Cultura $10 \quad$ (3); 6-18. http://dx.doi.org10.24917/20837275.10.3.1.

Barakat, Robert A. (1973) “Arabic Gestures.” The Journal of Popular Culture 6; 749-793.

Burgoon, Judee K., Jerold L. Hale (1984) "The Fundamental Topoi of Relational

Communication." Communication Monographs 51; 193-214.

Burgoon, Judee K., Laura K. Guerrero, Valerie Manusov (2011) “Nonverbal Signals.” [In:]

Mark L. Knapp, John A. Daly (eds.) The SAGE Handbook of Interpersonal Communication.

Thousand Oaks, CA: SAGE Publications; 239-280.

Бутовская, Марина [Butovskaya, Marina] (2004) Язык тела: Природа и культура. Москва: Научный мир.

Chapman, Ralph, Sam Dunn, Scot McFadyen (Writers) Sam Dunn, Scot McFadyen (Directors). (2011, December 3). Early Metal Part 2: UK Division (Season 1, Episode 3) [TV series episode]. [In:] Sam Dunn, Scot McFadyen (Producers). Metal Evolution. Banger Films. 
Dul, Robert (1993) “Gest w wystąpieniach publicznych.” [In:] Aldona Jawłowska, Marian Kempny, Elżbieta Tarkowska (eds.) Kulturowy wymiar przemian społecznych. Warszawa: Wydawnictwo IFiS PAN; 287-301.

Dunn, Sam, Scot McFadyen (Directors) (2007) Global Metal. Banger Films.

Efron, David (1941) Gesture and Environment. New York, NY: King's Crown Press.

Ekman, Paul, Wallace V. Friesen ([1969] 1981) "The Repertoire of Nonverbal Behavior: Categories, Origins, Usage, and Coding." [In:] Adam Kendon (ed.) Nonverbal Communication, Interaction, and Gesture: Selections from Semiotica. The Hague, Paris, New York: Mouton Publishers; 57-105.

Gajewski, Mariusz (2002) Satanizm w Polsce i na świecie. Kraków: D'el Art.

Jarząbek, Krystyna (1994) Gestykulacja i mimika. Słownik. Katowice: Wydawnictwo Naukowe "Śląsk".

Johnson, Harold G., Paul Ekman, Wallace V. Friesen ([1975] 1981) "Communicative Body Movements: American Emblems.” [In:] Adam Kendon (ed.) Nonverbal Communication, Interaction, and Gesture: Selections from Semiotica. The Hague, Paris, New York: Mouton Publishers; 401-419.

Kelly, Ken (2010) "Magic: A Tribute to Ronnie James Dio" [cover artwork]. On Various Artists (2010) Magic: A Tribute to Ronnie James Dio [CD]. Auburn, NY: Magic Circle Music.

Kendon, Adam (1981) “Geography of Gesture.” Semiotica 37 (1-2); 129-163.

Krüger, Reinhard (2004) "Fare le corna and the invention of a novel: Théophile Gautier's Gettatura (1857) and De Jorio's Mimica degli antichi (1832) or, problems of a gesture etymology." [In:] Cornelia Müller, Roland Posner (eds.) The Semantics and Pragmatics of Everyday Gestures. Berlin: Weidler; 33-57.

Knapp, Mark L., Judith A. Hall (2000) Komunikacja niewerbalna $w$ interakcjach międzyludzkich. Wrocław: Astrum.

Kreator (2020) London Apocalypticon - Live at the Roundhouse [BD]. Donzdorf: Nuclear Blast Records.

McNeill, David (2014) “The Emblem as Metaphor.” [In:] Mandana Seyfeddinipur, Marianne Gullberg (eds.) From Gesture in Conversation to Visible Action as Utterance. Amsterdam, Philadelphia: John Benjamins Publishing Company; 75-94.

Mertzani, Maria (2018) “The Ancient and Modern Mano Cornuta Use." Cadernos do Lepaarq 15 (30); 19-37. http://dx.doi.org10.24917/20837275.10.3.1.

Morris, Desmond (1994) Bodytalk: A World Guide to Gestures. London: Cape.

Morris, Desmond (2009) The Naked Man: A Study of the Male Body. London: Cape. 
Навасартова, Алина [Navasartova, Alina] (2017) “Денотативно-сигнификативные значения фигуры из пальцев 'коза'.” Язык. Текст. Дискурс 15; 130-136.

Obituary (2015) Live at Hellfest [Video]. Enorme TV.

Opeth (2007) The Roundhouse Tapes [DVD]. London: Peaceville Records.

Payrató, Lluís, Ignasi Clemente (2020) Gestures We Live By: The Pragmatics of Emblematic Gestures. Berlin: De Gruyter Mouton.

Quintilianus, Marcus Fabius ([35-96] 1920) Institutio Oratoria. Translated by Harold E. Butler. Cambridge, MA: Harvard University Press.

Ренев, Владимир [Renev, Vladimir] (2016) “Ораторские и благословляющие жесты в православной иконографии." Вестник Новгородского государственного университета 94; 119-122.

Robrue, Mett, Suthasinee Poungplub (2014) "Influence and Contemporary Culture of Hand Gesture 'The Sign of the Horns'.” Panyapiwat Journal 5 (2); 289-299.

Simmons, Gene (2010) Kiss and Make-Up. London: Cornerstone Digital.

Stoker, Bram ([1897] 1983) Dracula. New York, NY: Modern Library.

Сергеева Алла [Sergeeva Alla] (2006) Русские: стереотипь поведения, традиичи, ментальность. Москва: Флинта, Наука.

Ting-Toomey, Stella, Leeva C. Chung (2012) Understanding Intercultural Communication. New York, Oxford: Oxford University Press.

Weinstein, Deena (1991) Heavy Metal: The Music and Its Culture. Boulder, CO: Da Capo Press. Wise, Jessica Joy, Sam Dunn, Scot McFadyen (Directors) (2005) Metal: A Headbanger's Journey [Film]. Banger Films. 